\title{
The Contagious Diseases Acts and the Prostitute: How Disease And THe LaW ConTrolled the Female BODY
}

\author{
Kimeya Baker
}

\begin{abstract}
In this article, I examine the representation of prostitutes in the law, beginning with the Contagious Diseases Acts. These construct the female prostitute in a way that reflects Victorian sexual morality and gender expectations. I go on to explore how subsequent legal representations create complex discourses of prostitution in which the prostitute body is held as the site of the prostitute's sexual power, exploring Foucauldian theories of constructed sexuality and the use of disciplinary apparatus. I focus on the most significant legal changes in the regulation of prostitution since 1869 , and whether there are any remnants of the prejudices and views inherent in the Contagious Diseases Acts in legislation today. I argue that the current law remains unsatisfactory in regards to protecting the welfare of the prostitute and her right to the same protection and liberties as others, and explore the alternative approaches that the legislation may take. I contend that the criminalisation of prostitution does nothing to improve the situation; in fact, it only serves to maintain social stigma attached to the prostitute and ensures that she continues to be treated as a lower class citizen.
\end{abstract}

\section{A. INTRODUCTION}

Throughout the course of history, the prostitute has been the target of moral opprobrium, lambasted as the personification of both female oppression and social vice. She is at once diseased and immoral, treated by both legislation and society as the lumpenproletariat: more deviant and less valuable than even the lower-class citizen. Despite claims of women's sexual liberation, we are still quick to deny that we are promiscuous, flighty: anything that might indicate a similarity with the prostitute Other. Feminists, too, are disjointed, with those with a radical perspective decrying prostitution as the embodiment of female oppression, and liberal feminists believing that it represents sexual freedom and a shift away from Victorian expectations of female frigidity.

In this article, I examine the representation of prostitutes in the law, beginning with the Contagious Diseases Acts. These construct the female prostitute in a way that reflects Victorian sexual morality and gender expectations. I explore how subsequent legal representations create 
complex discourses of prostitution in which the prostitute body is held as a site of sexual power. I focus on the most significant legal changes in the regulation of prostitution since the introduction of the first Contagious Diseases Act in 1869, and whether there are any remnants of the prejudices and views inherent in the Contagious Diseases Acts today. I argue that the current law remains unsatisfactory in regards to protecting the welfare of the prostitute and her right to the same protection and liberties as others, and explore the alternative approaches that the legislation may take. I contend that the criminalisation of prostitution does nothing to improve the situation; in fact, it only serves to maintain social stigma attached to the prostitute and ensures that she continues to be treated as a lower class citizen.

\section{B. The influence of Foucault}

Essential to the understanding of the legal representation and regulation of prostitutes throughout history is the work of Michel Foucault. He understood power to be a positive multiplicity of force relations that impacts upon the minutiae of social life, creating minds and bodies through technologies of power ${ }^{1}$. The importance of ritualisation and normative social influence was evident within the structures of social institutions such as the prison and the school, and these practices created docile bodies that would, ultimately, undergo a process of self-regulation, internalising the norms propagated by the institutions and forming a type of self-surveillance, enabling bodies to be incarcerated without incarceration. $^{2}$

His study of the interplay between knowledge and discourses of sexuality identified the advent of a multitude of power mechanisms during the $19^{\text {th }}$ century that represented a new approach to sexual discourse. Sex was increasingly discussed, held up as a regime of truth in which the areas of medicine, psychiatry and science worked together to produce a new, medicalised discourse of sexuality. ${ }^{3}$ From this medicalisation, identities were formed: sex and sexual desire became something that defined a person, depending on whether or not they

\footnotetext{
${ }^{1}$ Michel Foucault, A History of Sexuality: An Introduction- Volume 1 (Random House 1990).

${ }^{2}$ Michel Foucault, Discipline and Punish: The Birth of the Prison (Vintage 1997).

${ }^{3}$ Foucault (n 1).
} 
adhered to the internalised norms expected and encouraged by the power influences in social institutions. Those who were classified as deviating away from the sexual norms became the subject of intense medical and psychiatric scrutiny, and this classification system produced different discourses of pleasure, discipline and truth. ${ }^{4}$

Foucault also noted the way in which the relations of power track and produce bodies through different discursive practices. ${ }^{5}$ He explored the way in which a body moves through different disciplinary apparatuses after breaking the law, from the prison through to the court, and noted that interposed at each point were various mechanisms of power that produce classifications and transform the body into the disciplined, delinquent body. ${ }^{6}$

While Foucault only occasionally addressed the issue of gender difference in his work, his understanding of the relationship between power and the body has been essential to feminist thought. His work has been appropriated for use alongside analyses of the different constructions of male and female sexualities. Through Foucault's understanding of the body as a site of political power, his theories lend a greater depth of understanding to the way in which the law may gender the female body. McLaughlin explores these ways in relation to sex work, noting that, firstly, the prostitute was constructed as predominantly female. ${ }^{7}$ Secondly, prostitutes have been constructed in stark opposition to more appropriate manifestations of womanhood, portraying deviant forms of female behaviour, and therefore being classified as dangerous and pathological. ${ }^{8}$ As will be explored in this article, Victorian beliefs regarding the immorality of sex work were intricately tied in with notions of appropriate female sexuality and pervasive patriarchal hierarchies within both society and the home. Finally, the female prostitute body has been traditionally regulated via medical procedures backed by the support of the law, institutional management in psychiatric studies of sexuality, and incarceration. From this, we can understand the body of the prostitute

\footnotetext{
${ }^{4}$ ibid.

${ }^{5}$ Lois MacNay, Foucault and Feminism (Cambridge 1992).

${ }^{6}$ Foucault (n 2).

7 Lisa McLaughlin, 'Discourses of Prostitution/Discourses of Sexuality' [1991] Critical Studies in Mass Communication 8.

${ }^{8}$ ibid.
} 
as, historically, a site for the manifestation of power, knowledge, and sexual discourse.

According to Foucault, modern disciplinary apparatuses function to produce docile bodies. ${ }^{9}$ Walkowitz notes that through this process, the female prostitute body is constructed via its identification in legal discourse and regulation. ${ }^{10}$ The law serves to make assumptions about the nature of the problem of prostitution, and thus regulates accordingly. Any legal response to prostitution has to depend on what the harm is identified as, and so if we perceive the harm as X, then the law will correspondingly look like X. Thus, the Contagious Diseases Acts represented a marriage between medico-legal discourses, reflecting the increase of scientific knowledge regarding health, concepts of Victorian morality and the belief that the law should intervene to control both. This supported the Foucauldian notion of biopower, a concept of political power that focused on the importance of state regulation of bodies and physical health in maintaining systems of power relations and controlling and regulating the population.

\section{The Contagious Diseases ACts: a Brief History}

Before the advent of the Contagious Diseases Acts, prostitution was a target of vilification from both religion and the law. However, with the $19^{\text {th }}$ century came a reinvigorated aim to regulate prostitution in a more systematic way. Section 3 of the Vagrancy Act of 1824 stated, '...every common prostitute wandering in the public streets... and behaving in a riotous or indecent manner... shall be deemed an idle and disorderly person...'. The emphasis on the link between prostitution as a sexual crime or an issue of immorality and contagion only appeared fully to mature with the Contagious Diseases Acts of 1864, 1866 and 1869 (hereby referred to as the $\mathrm{CD}$ Acts with their respective dates).

The CD Act 1864 was introduced following general concerns within the military regarding the number of hours lost through soldiers contracting venereal infections from prostitutes. The focus was on inculcating a new ethos of moral masculinity within the military as part of

\footnotetext{
${ }^{9}$ Foucault (n 1).

${ }^{10}$ Judith Walkowitz, Prostitution and Victorian Society: Women, Class and the State (CUP 1980).
} 
a widespread reform programme that created a more celibate army- an effort to 'increase the efficiency of the armed forces by decreasing the cost of treating venereal diseases amongst the bachelor troops'. prostitutes were portrayed as wartime harpies, infecting the troops and thus indirectly impacting the safety and stability of the State.

The solution to this was seen as the creation of an institute in which such soldiers could be inculcated, whereby they would develop a taste for 'harmless and improving recreations'. ${ }^{12}$ These recreations would create a masculinity based upon self-control, holding 'the appetites and passions...in abeyance...by a training of the mental facilities'. ${ }^{13}$ The prostitute would also need to be regulated and prevented from infecting both the health and morality of the troops. This represented a regulationist approach in which prostitutes and lower-ranked women were identified, their characteristics constructed and codified, within military discussions over questions of morality. The soldier's self-control was created in juxtaposition to the prostitute's debauchery, and the internal order of the newly regulated army morality was opposed to the disorder of urban centres of diseases and crime. ${ }^{14}$

Under the 1864 Act, the Superintendant of Police, on information from one of his plainclothes constables, had to inform a magistrate that a woman was a common prostitute with a contagious disease, who had, within the previous fortnight, been in a named street within the boundaries set out in the Act. According to the Act, any woman could be charged with prostitution upon the testimony of a police inspector, superintendant, or medical examiner before a magistrate. The burden of proof was on the woman to convince the courts that she was not a prostitute. If she failed to do so, she was forced to undergo a mandatory vaginal examination by an army surgeon. If she were infected, she would be sentenced to three months detention and treatment in a lock hospital. If, at any point, a woman failed to comply with the conditions of the Act,

\footnotetext{
${ }^{11}$ Linda Mahood, The Magdalenes: Prostitution in the Nineteenth Century (Routledge 1991) 138.

${ }^{12}$ Miles Ogborn, 'Law and Discipline in Nineteenth Century English State Formation: The Contagious Diseases Acts of 1864, 1866 and 1869' [1993] 6 Journal of Historical Sociology 1, 35.

13 ibid.

${ }^{14}$ ibid.
} 
she would be subject to one month's imprisonment for the first offence, and two months for every offence thereafter. Any refusal to submit to the will of law, either at the point of examination or incarceration, was once again punishable by the courts. It must be noted that the courts were interposed at every important point, as a woman moved along a path from freedom, to examination, to incarceration. The Acts were, truly, a marriage between 'medical discourses of disease control, moral discourses over the ordering of dangerous sexualities, and legal discourses of crime and punishment'. ${ }^{\text {, }}$

The term 'common prostitute' was undefined, enabling the authorities to retain broad discretionary powers about what could constitute a common prostitute, although the act was reliant on the premise that only females could be defined as such. This gender distinction was continued throughout the Act, as it dictated that only women could be examined for venereal disease. By enforcing this distinction, the efficacy of the Acts was undermined from the outset- any medical aim invoked by the creation of the Acts was rendered ineffective by the exclusion of men from medical examination for venereal disease. Without ensuring that men were similarly regulated and prevented from spreading the disease to women, the Acts appear to be premised upon the implication that women were the sole cause of the spread of infection, and that they were already so degraded by their own lifestyle choice that any further debasement was unimportant.

The 1866 Act forced identified prostitutes to undergo an examination every three months, on the evidence of an appointed official before a magistrate. A woman could apply to the court to be released from the rescue hospital, or removed from the inspection registration if she could prove that she was no longer a prostitute. The geographical jurisdiction of the Acts was expanded under the 1866 addition, stretching to Southampton and Winchester, and an extension of five miles around the parishes was established. This was judged to be an inadequate expansion, and so under the 1869 Act this was extended to a 15-mile radius around the towns, preventing prostitutes from commuting into the districts by making it too inconvenient. Furthermore, a clause was added

\footnotetext{
${ }^{15}$ ibid.
} 
into the Acts by which women could be incarcerated, without trial, for five days before their examinations.

The medical profession propounded the Acts on a sanitary basis, and the civilian elite used their political influence to get the Acts passed, creating a piece of legislation that reflected a new interventionist phase to Victorian health and social issues. This emphasis on sanitary conditions 'perceived public order as synonymous with public health', ${ }^{16}$ and played upon fears over social health to control street vice and increase the surveillance of the working class.

However, some supporters saw the Acts as protecting the chastity of middle-class females, who would otherwise be vulnerable to sexual predation from gentleman who could find no other release. This belief permeated public feeling to such an extent that women, too, were supportive of the Acts, despite its obvious gendered discrimination ${ }^{17}$. Indeed, preceding, during and following the repeal of the CD Acts, proponents argued that prostitution actually served to solidify marriage by acting as an escape route by which husbands may satisfy their sexual frustrations and thus remain in their relationships. This appeals to the idea that men cannot control or resist their strong sexual desires, and should therefore be allowed access to prostitutes as some form of release so that they can continue to be otherwise faithful in their marriages. This belief is built upon the premise that the wife in the marriage does not discover her husband's infidelity, or, indeed, if she does find out, should waive her right to be angry, allowing the sexual indiscretion as some form of 'marriage therapy'. It provides a good example of the hypocrisy involved in the criminalisation of prostitution, whereby the white, male majority in political power may publically condemn prostitution as immoral, and yet, as outlined below, the typical clients of prostitutes are just these kinds of men - the middle-class, 'Mr Average's, with the disposable income to afford such habits.

Opposition to the Acts came predominantly in the form of Josephine Butler's Ladies National Association, which consisted of feminists, anti-statists and Northern labour aristocrats, collectively

\footnotetext{
${ }^{16}$ Mahood (n 12) 141.

${ }^{17}$ ibid.
} 
dubbed the 'shrieking sisterhood'. ${ }^{18}$ This disjointed band of reformists opposed the Acts for portraying the ultimate double standard of punishing women whilst turning a blind eye to their male counterparts. They argued against the examination of the women themselves, likening it to a form of instrumental rape, and rallied against the Acts for 'legislating for the state's active encouragement of vice in the form of a rapacious male sexuality'. ${ }^{19}$ However, Brophy noted that during the $19^{\text {th }}$ century many believed that women had a superior sexual morality, and so it was difficult for them to support a campaign that embraced women who were regarded as lax in moral standards. ${ }^{20}$ Because of this reluctance, their support came in the form of an uneasy defence of female morality as a whole, with a middle-class emphasis upon rescue homes for prostitutes, created to ensure that they were reformed, encouraged to give up their promiscuous activities and turned into respectable Victorian women. Between 1870-1885, the opposition presented petitions to the House of Commons, took part in rallies, formed meetings and raised public awareness, finally managing to appeal to public sentiment and overturn the Acts in 1886 .

The gendered constructs prevalent within the CD Acts saw the behaviour of prostitutes as corrupting, and autonomous sexuality as something to be feared. The significant gendered distinction inherent within the $\mathrm{CD}$ Acts was that of the naturalness of male sexuality contrasted against the unnatural female sexuality. Men were not to be blamed for attempting to fulfil their natural sexual urges. Conversely, prostitutes were deviant, unnatural, and sick. Police were supposed to be able to recognise a prostitute just by looking as her, as if sexual immorality was so self-evidently visible as to record itself on the body.

This understanding of the prostitute as motivated by an insatiable sexual urge that could only manifest itself by working on the streets overlooks the myriad of reasons as to why a woman may turn to sex work, both at the time of the CD Acts and today. Far from a rampant sexuality that renders the career choice attractive, women may be

\footnotetext{
${ }^{18}$ Ogborn (n 13) 48.

${ }^{19}$ ibid 47.

${ }^{20}$ Julia Brophy and Carol Smart, 'Locating Law: a Discussion of the Place of Law in Feminist Politics' in Julia Brophy and Carol Smart (eds), Women-In-Law: Explorations in Law, Family and Sexuality (Routledge 1985).
} 
motivated by financial reasons, a lack of qualifications for other jobs, or alcoholism or drug addictions that cause them to be vulnerable and desperate. McLeod's more recent interviews with sex workers supports the rejection of prostitution as a form of sexual gratification, as the prostitutes generally state that they feel nothing during sexual intercourse, choosing to switch off any emotional involvement or potential feelings of physical pleasure. ${ }^{21}$ Indeed, the clients complain that the process is too clinical and emotionless, resembled a medical procedure rather than an intimate, sexually stimulating experience. ${ }^{22}$ The Contagious Diseases Acts failed to acknowledge these alternative motivations, instead turning to sexuality as the easy answer to a difficult question.

\section{Assumptions AND Motivations UNDERLYing THE Contagious DISEASES ACTS}

Shrage identified certain assumptions regarding gendered sexuality that, she argues, lead to the oppression of women, including prostitutes. ${ }^{23}$ The first assumption is that the 'naturalness' of sexual desire is elevated to a scientific truth, as evidenced above. Ericsson supported this, stating, 'our sexual desires are just as basic, natural and compelling as our appetite for food'. ${ }^{24}$ However, Pateman cleverly counteracts this notion: '(w)ithout a certain minimum of food, drink, and shelter, people die; but, to my knowledge, no one has yet died from want of sexual release'. ${ }^{25}$ In claiming that such sexual desires for intercourse are natural, one is adhering to a masculine understanding of what is 'natural' and enforcing the same standard on women. The 'naturalness' of such desire is unclear: women may well be as sexually voracious as their masculine counterparts, but have been constrained and suppressed by the expectations of society and the morality propounded by the pressures of the law. With no empirical evidence either way, it is fallacious to treat a typically masculine conception of sexuality as an absolute truth.

\footnotetext{
${ }^{21}$ Eileen McLeod, Women Working: Prostitution Now (Croom Helm 1982).

22 ibid.

${ }^{23}$ Laurie Shrage, Moral Dilemmas of Feminism: Prostitution, Adultery, and Abortion (Routledge 1994).

24 Lars Ericsson, 'Charges Against Prostitution: an attempt at a Philosophical Assessment' [1980] 90 Ethics 335, 341.

${ }^{25}$ Carole Pateman, 'Defending Prostitution: Charges Against Ericsson' [1985] 93 Ethics 563, 563.
} 
The second assumption is that men are naturally dominant, and this could be used to explain why men seek out ways to release their sexual urges via the sexual domination of female prostitutes. However, the difficulty with testing the validity of this statement is that much political, legal and sociological thinking is premised on the same belief, thus creating and sustaining a world in which men are allowed to be dominant, simply because it is 'natural'. This need for dominance is supported by some interviews with prostitutes conducted by McLeod, ${ }^{26}$ but, regardless of whether this dominance has simply been encouraged and perpetuated by males in positions of power, or whether it is a natural fact that even a cultural/difference feminist would acknowledge, it does not excuse the domination of men over female bodies. Because something is natural does not necessarily make it acceptable; one could argue that it is natural for humans to war against each other and exact revenge by killing others, and yet this is quite clearly prohibited by legislation.

The third assumption is based upon the premise that sexual contact with males pollutes women. Primoratz holds that such an assumption is no longer viable today, stating: 'That particular way of valuing women and the whole 'Madonna or harlot' outlook to which it belongs are well behind us as a society'. ${ }^{27}$

However, this statement isn't particularly self-evident. Frug notes that 'the sexualisation of the female body explains an experience many women have: an insistent concern that this outfit, this pose, this gesture may send the wrong signal - a fear of looking like a whore. ${ }^{28}$ She maintains that this fear permeates any instance in which a woman has sex for unromantic reasons, countering Primoratz's idea that the notion of female sexual currency is no longer viable. The words bandied around in everyday use by teenagers and adults alike, such as 'slut' and 'whore', make it clear that the days of acceptance of female sexual liberation are not yet upon us, particularly as there appears to be no male counterpart to such terms. 'Love-rat' might be the closest we get- close, and yet so far.

The final assumption is that a person's sexual activities, desires or motivations somehow dictate the kind of person they are, whether a

\footnotetext{
${ }^{26}$ McLeod (n 21).

27 Igor Primoratz, 'What's Wrong With Prostitution?' [1993] 68 Philosophy 264, 179.

${ }^{28}$ Mary Frug, Postmodern Legal Feminism (Routledge 1992) 132.
} 
prostitute, a homosexual, or a heterosexual. This kind of thinking is evident within the CD Acts and the cultural beliefs that stimulated their creation, classifying the prostitute by her occupation alone (and, furthermore, her gender). Sexuality creates a form of identity that defines a person, tied to the belief that society's 'future and fortune were tied...to the manner in which each individual made use of his sex'. ${ }^{29}$ Sex was policed and controlled as a key method of both sustaining and challenging the operation of power, and thus became a concern for those who wished to control the ways in which sexuality was discussed and acted upon.

A similarly valuable tool to the cause of the CD Acts was the medicalisation of sexuality and prostitution. By its very definition in various textbooks, venereal disease was 'the contagious disease that men are apt to catch by dealing with infected women'. ${ }^{30}$ Prostitutes somehow become the personification of the disease itself, their internal infection reflecting the immorality of their actions. The connection between their diseased bodies and diseased morality was a powerful one, and the language used in the discussion of prostitution, infection and morality picked up on the metaphor as a significant instrument of coercion. Lombroso's sociological studies further supported the idea of the prostitute as pathological, suggesting that prostitutes suffered from a medical condition that could be hereditary. ${ }^{31}$ Although since disregarded by nearly all theorists, his work lent support to the theory of difference that has persisted for many decades, and has inevitably coloured the underlying social perception of the prostitute since.

The link between political motivations and the language used in relation to the prostitute was also observed by Mahood, who likened the classification of the prostitute to that of a homosexual, a category 'invented by moral reformers who wished to impose an 'alien' interpretation on the activities of working class women'. ${ }^{32}$ It was not

\footnotetext{
${ }^{29}$ Foucault (n 1) 26.

${ }^{30}$ Lucy Bland, 'In the Name of Protection: the Policing of Women in the First World War' in Julia Brophy and Carol Smart (eds), Women-In-Law: Explorations in Law, Family and Sexuality (Routledge 1985) 28.

31 Cesare Lombroso, Criminal Woman, the Prostitute, and the Normal Woman (Nicole Hahn Rafter and Mary Gibson trs, Duke University Press 2004).

${ }^{32}$ Helen Self, Prostitution, Women and Misuse of the Law: The Fallen Daughters of Eve (Frank Cass 2003) 23.
} 
necessarily bound up with their occupation, either: so long as these women were wearing particular clothing or acting in a particular way, they could be labelled a prostitute and cast out from the acceptance of society. She held that 'the definition of who was or was not a prostitute was deeply political'. ${ }^{33}$ Spender further argued that women have been excluded from the production of cultural forms, including language. Language has been created by men to reflect masculine meaning and purpose, and therefore any body of knowledge is founded upon gendered inequalities, from its content to its very basic form. ${ }^{34}$ This is significant in that not only is the prostitute isolated from legal and social participation, the female generally is forced to exist within inherently masculine formulations of information and knowledge. The female is alienated from the outset, and simply abolishing a law or passing a statute cannot remedy this, as it is so fundamental and endemic within the nature of knowledge as to require a complete reconstruction of language and cultural forms. Furthermore, each party to the prostitution debate was gendered: the male doctors, judges, policemen and politicians; the female prostitutes, respectable mothers and the emotional 'shrieking sisterhood' of the opposition.

Despite these grouped genders, the differences between the prostitute female and the 'moral' female were emphasised and the two identities were constructed in opposition to each other. The prostitute was shunned for her wanton display of sexuality, and behaviour that was not becoming of women who should be training to take on a sexually passive role as wives and mothers: 'immodesty, unwomanly behaviour, vanity and love of finery'. ${ }^{35}$ This ties in with the Foucauldian notion of the 'Other', by which identities are isolated and excluded by society because they do not fit in with the morality or expected roles. In the process of Othering, people create their own identities in reaction to the stigmatisation of these 'deviant' groups, and justify the rejection and exploitation of these groups on the basis of their Otherness. Prostitutes were made to appear not merely as fallen women, but something less than women. Self acknowledges that the prostitute and the mother were thus

\footnotetext{
33 ibid.

${ }^{34}$ Dale Spender, Man Made Language (Pandora 1998).

${ }^{35}$ Self (n 32) 23.
} 
created in direct opposition to each other, with the prostitute's body representing the overly sexualised female body, and the 'moral' woman representing the desexualised, maternal body. ${ }^{36}$ This was a battle of opposites: the flighty prostitute and her abnormal over-indulgence of sexual desires and sterility, and the fertile, virtuous and sexless woman; the fallen versus the upright.

Far from being founded on a notion of the value of the female body and feminist rights, it may be argued that the negativity evident during the $\mathrm{CD}$ Acts era towards the practice of prostitution may have been predicated on traditional white, Christian views that hold up the monogamous marriage as the ideal. The further a sexual union strays from this ideal, the less regard it is to be held in, and this sentiment is evident even today with the conservative emphasis upon the traditional familial unit, and the legal prioritisation of marriage over civil partnerships and cohabitation. Under this view, sex should be reserved for marriage alone, and this underlying feeling may explain why, historically, prostitution was considered to be a blight upon society. Furthermore, Foucault's repressive hypothesis explains the connection between economy and the proliferation of sexual discourses. Wanton extramarital intercourse was neither aimed at procreation, nor provided a medium of displaying affection, and was merely an unproductive distraction from the most important goal for the bourgeoisie: an industrious work ethic. ${ }^{37}$ This repressive hypothesis demonstrates the power of the bourgeoisie in controlling sexual discourse by deciding how sex could be discussed, and therefore controlling the kind of knowledge we have regarding sex. Because knowledge is intricately linked with power, their control over such discourses maintains their power and ensures that they can confine sex to circumstances in which it is productive, and does not oppose the work ethic the bourgeoisie wish to promote.

However, Foucault rejects the link between the ascendance of capitalism and the repression of sexuality, holding that this explanation is inadequate in explaining the deployment of power, knowledge and sexual confession. ${ }^{38} \mathrm{He}$ further notes that, rather than using the deployment of

\footnotetext{
36 ibid.

${ }^{37}$ Foucault (n 1).

38 ibid.
} 
sexuality to regulate the working classes from above, 'the most rigorous techniques were formed... and applied...in the economically privileged and politically dominant classes, ${ }^{39}$ and its successive evolution created class effects.

Smart claims, in addition, that the fear bound up in the CD Acts was not only of the danger of gendered sexual behaviour, but racial. She notes that the concept of morality during the $19^{\text {th }}$ century was a white one, with those who failed to meet those standard castigated as 'less than British'. 40 Much like the second wave of fear of prostitution after World War Two, fear of sexuality and a digression from the military needs and work ethic appears to be inextricably linked to feelings of imperialism and the globalisation of Christian morality. Nead holds that 'questions of military needs, empire and colonial trade could easily be reframed as issues of morality, health and national strength'. ${ }^{41}$ Extramarital sex and the general indulgence of vices became viewed as much a threat to the home front as warfare itself.

\section{E. Consequences of THe Acts}

The Acts continued to perpetrate notions of female sexuality as inherently diseased, holding the prostitute up as the paradigm example of fallen immorality and using her as a scapegoat for as all that was considered wrong with social morals at the time. They created negative effects whereby females were defined and bound by their occupation as prostitutes. While the direct physical consequences of the Acts were clear, in that they created the potential to subject women to internal examinations and incarceration under the control of masculine medicolegal surveillance, they also had other indirect effects. By forcing the categorisation and registration of prostitutes, this essentially ended the kind of part-time prostitution in which women were able to dip in and out of work when they faced financial difficulty, and locked the woman into the social identity of 'prostitute'. Furthermore, the law also provided an

\footnotetext{
39 ibid 120.

${ }^{40}$ Carol Smart, Regulating Womanhood: Historical Essays on Marriage, Motherhood, and Sexuality (Taylor and Francis 1992) 25.

${ }^{41}$ Lynda Nead, Myths of Sexuality: Representations of Women in Victorian Britain (Blackwell 1998) 84.
} 
excuse to put more police on the streets in working class areas, thereby increasing the surveillance of the whole neighbourhood and attempting to collect other social ills within the fine mesh of its net.

It is all too easy to look back on the history of the Contagious Diseases Acts and the legal control of the female body and confine it to its circumstances, dismissing it as a product of repressive Victorian sexuality and gender issues. However, Foucault warns against creating a category of 'us and them' in respect of Victorian values, and against allowing this 'repressive hypothesis' to dominate our modern-day discourses on sexuality. In fact, he claims that Victorians actually involved themselves in a multiplication of discourses concerning sex, exhibiting 'an institutional incitement to speak about it, and to do so more and more'. ${ }^{42}$ While what he calls a 'discursive explosion' on sexuality was often produced as a means to contain and control sexuality, it is possible to argue that, just as those that came together to create the Contagious Diseases Acts, the apparatus of social, medical and legal enforcement created a set of morals, rather than morality being produced out of a repressed silence about sexual matters.

The repressive hypothesis has now, itself, become a form of discourse, whereby we talk about the ways in which we cannot talk about sexuality, and view our longing of sexuality as some form of rebellion against the Victorian norm and the politically bourgeois society. Foucault "charged us with championing our own sexual progressiveness by "othering" the Victorians...narrating our liberation from repressive "Victorian" moralities'. ${ }^{43}$ We now consider ourselves liberated from our Victorian prudishness, and castigate those who longingly look back to the traditional values of the $19^{\text {th }}$ century. In order to achieve a level of selfawareness regarding our sexualities under this false image of the repressed Victorian counterpart, repression is used as a method by which we are placed outside of the reach of the power- by speaking about sex, we consider ourselves rebellious, liberated, 'deliberately transgressing' the restrained sexuality that we have attributed to our former selves. It is important, in the case of prostitution, that we do not distance ourselves

\footnotetext{
${ }^{42}$ Foucault (n 1)18.

${ }^{43} \mathrm{P}$ Howell and D Beckingham and F Moore, 'Managed Zones for Sex Workers in Liverpool: Contemporary Proposals, Victorian Parallels' [2008] 33 (2) Transactions of the Institute of British Geographers, 235.
} 
from our fictional, repressed Victorian cousins, considering ourselves accepting of various expressions of sexuality. This is not accurate, and paints a gloss over the oppression and opposition that those with 'deviant' sexualities- prostitutes, homosexuals and transsexuals- have faced, and continue to face in modern culture. Foucault held that the modes of power that dealt with peripheral sexualities were highlighted and incorporated into the power of the law, rather than prohibited. However, it is interesting to note that, while both social and legal acceptance of homosexuality has increased, the same cannot be said for the prostitute.

\section{F. THE 1950S}

The abolition of the Acts did not signify an evolution from the view of female sexuality as deviant and immoral. The next significant wave of moral conjecture regarding prostitution was in the $1950 \mathrm{~s}$, motivated by the advent of an increased awareness of sex, and a focus upon the importance of sexual intercourse in saving the marital bond from the interruptions and incursions of the war. Prostitutes were therefore viewed as threatening the harmony of wedlock, and the ability to rebuild potentially vulnerable marriages after the end of the war. These 'war-time harpies' were once more constructed as pathological, and psychologically flawed. Chesser noted that 'girls themselves would not become prostitutes unless their emotional natures were warped and unstable to begin with, ${ }^{44}$ harking back to the notion of the Other as represented by the deviant and pathological characterisation of the prostitute under the CD Acts. Much like the emphasis upon the protection of the Empire and ascribing to a 'white' morality around the time of the CD Acts, war-time nationalism gave rise to a wave of fear of the racialised Other, represented by West Indian and Maltese men who were viewed as causes of prostitution and the control of sex work, posing a threat to British morality.

The Wolfenden Committee was created in 1954 to provide educated recommendations on the legality of homosexuality and prostitution, eventually publishing the Wolfenden Report. ${ }^{45}$ This placed

44 Eustace Chesser, Live and Let Live: the Moral of the Wolfenden Report (Heinemann 1958) 123.

${ }^{45}$ Committee on Homosexual Offences and Prostitution, Report of the Committee on Homosexual Offences and Prostitution (1957) Her Majesty's Stationary Office. 
considerable emphasis on the public/private divide in relation to prostitution, holding that prostitution that was out of the public realm was an issue of private morality, and the law should not interject in such affairs. On the other hand, prostitution that occurred in the public eye and offended public morality was a concern, and should be regulated and prohibited by the law. This clearly placed more importance on keeping sex workers off the streets and preventing them from offending the delicate sensibilities of everyday citizens, as opposed to considering the danger and difficulties of prostitution. The focus was also upon criminalising the female prostitute (rather than the male client), based on the rationale that the women had already associated themselves with criminal activity, therefore distancing themselves from society and the legal rights that others have. In addition, their behaviour was considered 'a nuisance' to the public sphere, much like the rationale behind the CD Acts.

By relegating prostitution to the criminal underbelly of society and turning a blind eye to their activities so long as they occurred within the private sphere, the Wolfenden Report fell foul of the same public/private issues that dominate the law today. Freeman acknowledges the flaws of public/private distinction in respect of modern laws regarding domestic violence. ${ }^{46}$ Women are at greater risk from sexual and domestic abuse from their partners rather than strangers in the public sphere, and yet the law treads carefully in cases of domestic violence, in fear of crossing the demarcated boundaries of the public/private divide. Prostitutes are similarly vulnerable from abuse from their pimps and, indeed, from clients, and yet crimes against prostitutes go generally overlooked. Furthermore, both Foucault and certain feminist schools of thought reject the artificial political construction of the public/private divide, ${ }^{47}$ noting that political power is omnipresent: 'between every point of a social body, between a man and a woman...between a master and a pupil,

\footnotetext{
${ }^{46}$ Michael Freeman, Violence in the Home: a Socio-Legal Study (Saxon House 1980).

${ }^{47}$ See generally: Vanessa Munro, 'Feminism(s) Law and Liberalism(s)' in Vanessa Munro, Law and Politics at the Perimeter: Re-evaluating Key Debates in Feminist Theory (Hart Publishing, 2007); and Frances Olsen, 'Constitutional Law: Feminist Critiques of the Public/Private Distinction' [1993] 10 Const. Comment 319.
} 
between everyone who knows and every one who does not'. ${ }^{48}$ It is useful for juridico-political discourse to appeal to the notions of the public/private divide in order to placate liberals, but in actuality, power formations are pervasive. When the law seeks to restrict prostitution to the private sphere, or fails to fully address incidences of domestic violence because it is an issue of private morality, it is holding up the battered wife or the coerced prostitute as something that it takes no interest in. This, in turn, allows the worst kinds of male oppression to occur, safe in the knowledge that hiding within the blind spot of the law protects them.

The deliberations of the Wolfenden Committee and its report were followed by the Street Offences Act 1959, which once more enforced harsh penalties for prostitutes. Section 1(1) provided that '[i]t shall be an offence for a common prostitute to loiter or solicit in a street or public place for the purpose of prostitution'. A woman could be charged under the Act after being cautioned for loitering or soliciting and being found to continue to do so on a subsequent occasion (s.2(1)). The sex-specific construction of the label was upheld in D.P.P $v$ Bull, ${ }^{49}$ where a male prostitute was dismissed on the basis that s.1(1) only applied to female prostitutes. A further feature of the offence under s.1(1) is that it required that the act of loitering or soliciting take place in a 'street or public place'. This requirement was very much in line with the interpretation of the 'problem' of prostitution as articulated in the Wolfenden Report and with what Lord Taylor referred to as 't[he] mischief [of prostitution] being...the harassment and nuisance to members of the public on the streets'. ${ }^{50}$

The construction of the 'prostitute' was once more as an identity category, not a normal worker in a profession, seeking to earn money. The continued emphasis on the (specifically female) prostitute as the problem of social ills upheld the beliefs of the Contagious Diseases Acts. This was further buttressed by the pathologisation of the prostitute, who was seen as physically diseased, and psychologically flawed. The harsh penalties and lack of civil rights compared to other citizens were based on

${ }^{48}$ Michel Foucault, Power/Knowledge: Selected Interviews and Other Writings (Pantheon Press 1980) 187.

${ }^{49}$ [1995] QB 88.

${ }^{50}$ Regina v McFarlane [1994] 99 Cr App R 8; 58 JCL 374. 
a woman's lack of sexual rectitude, which had implications for all women, not just those labelled 'prostitutes'. It condoned the notion that women need to remain respectable or lose their legal rights, as if such basic rights to bodily integrity and protection were precariously hanging in the balance at all given times, depending on the sexual behaviour.

\section{G. Current Laws and Regulation}

The Policing and Crime Act 2009 (sections 14 to 21) inserted into the Sexual Offences Act 2003 sections relating to prostitution. It created further penalties for 'soliciting for sex', replacing the offences of kerb crawling and persistent soliciting under sections 1 and 2 of the Sexual Offences Act 1985. It also criminalised paying for sex with a prostitute who is 'subject to force or coercion' and/or exploitation. It made the process easier for police to close premises associated with prostitution or pornography related offences, including the offence of causing, inciting, or controlling prostitution for gain. These terms are broadly couched, and represent a shift from the Wolfenden strategy of ignoring sexual activities in the private sphere. This benefits prostitutes in that they are no longer dismissed as 'out of sight, out of mind', relegating them to the margins of society in order to avoid punishment. However, to measure the benefits, it is essential to understand through which perspective one is making such an analysis. The radical feminist who rallies against prostitution as the ultimate example of male dominance over the female body may welcome such intrusion as a method of protecting prostitutes and rendering it difficult for them to continue their jobs as sex workers. On the other hand, the liberal feminist may take a number of different standpointssupportive of the fact that greater police presence will protect the prostitute from falling into the cracks of society, unnoticed and vulnerable, or may alternatively feel that the police presence impinges on her ability to choose to take part in such a career. Throughout this article I have favoured a liberal feminist approach that acknowledges the ability of women to make their own life decisions, however unpalatable, is to be preferred over a more radical feminist school of thought that would wish to prevent them from subjecting themselves to a seemingly oppressive and dangerous lifestyle. Paternalism can quickly resemble patriarchy, and arguments in defence of morality may only serve to isolate and alienate 
the female sex worker further. Nevertheless, it is important to acknowledge the various possibilities of feminist thought and the ways in which these approaches may consider prostitution and its regulation.

In the Sexual Offences Act 2003, the term 'prostitute' was defined as applicable to both males and females, thus rendering the DPP $v$ Bull ruling obsolete. However, the ramifications of making 'prostitute' gender-neutral are not yet clear. Although, in theory, this has widened the scope of law and represents a step towards equality and fairness in criminalising prostitution, its general application does not achieve much, as sex workers are overwhelmingly female. Interestingly, in Working Women: Prostitution Now, ${ }^{51}$ interviews with male prostitutes shed light on the process, indicating that the dynamic is also different between female customers and male sex workers. One male prostitute noted that:

The taboo on women resorting to male prostitution was so ingrained, that even when a woman was obtaining sexual relief...she couldn't admit that it was a desire that existing among women, a possibly legitimate need, as oppose to a unique, unnamed proclivity. ${ }^{52}$

This highlights the fact that female sexuality remains unacceptable in society, even to the woman herself; such a belief was not overturned with the Contagious Diseases Acts. This reinforces the notion prevalent within the 1800 s that men's strong sexual urges are natural and unable to be restricted, whereas female sexuality is wanton and deviant. Martin, a client in one of McLeod's interviews, also propounds this idea, remarking: 'usually it's the female who has been the prostitute...why? It must be because the male urge is more'. ${ }^{53}$ Many prostitutes also ascribed to this view, with McLeod noting, 'they seem to adopt the conventional view that men's sexual urges need to take pride of place'. ${ }^{54}$

Several clients also made a connection between the prevalence of prostitution and rates of rape offences. Derek states: 'Where you get prostitution, you don't get rape. Men have no need to rape girls...he can

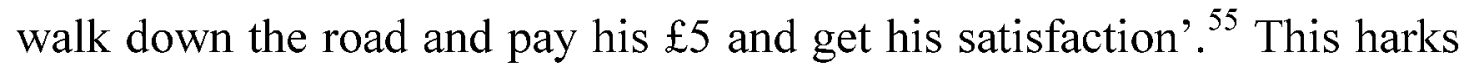

\footnotetext{
${ }^{51}$ McLeod (n 21).

52 ibid 62.

53 ibid 65 .

54 ibid.

55 ibid.
} 
back to the proponents of the CD Acts, who argued that prostitutes were necessary in order to control the male sexual urges and ensure the safety of the wives and virgins who may otherwise by attacked. Note how, despite the idea of men attacking women when left without some form of release, this apparent masculine barbarism is glossed over, and the prostitute instead becomes the deviant.

Although the specific act of prostitution- performing sexual services for money- is not illegal under current legislation, loitering, soliciting and controlling prostitution for gain are, leaving the prostitute socially and legally isolated once more. Duncan argues that:

the law... raises the spectre of an offence for almost everyone who comes into contact with her and upon whom she depends for her survival. She is, therefore constructed as a pariah- a legal leper who may infect all she meets. ${ }^{56}$

The language of disease and infection returns, highlighting the effect that the law has had upon perpetuating the social exclusion of the prostitute. Much like the CD Acts served to portray her as infected and almost subhuman, the prostitute remains a legal leper. This is creates a vulnerability and a dependency which has enabled pimps to gain control of prostitutes and offer them protection. Pimps may be seen as the personification of the masculine oppression over the female body: it is no longer hypothetically argued that the sex worker is controlled by male hegemony for her sexual services- it is here in the flesh.

The Sexual Offences Act does make some provision for criminalising pimps, with s.52 making it an offence for a person to intentionally cause or incite another into prostitution, where that person does so for or in expectation of gain for himself or a third party. Section 53 further makes it an offence that a person to intentionally control a person's activities relating to prostitution, with the same pecuniary intentions as s. 52. In addition, in s.53(a) it is made illegal for clients to pay for sexual services of a prostitute subjected to exploitation and/or force, regardless of whether they are aware of an external person exploiting the prostitute. This legislation represents a positive attempt to place the blame and focus on pimps and clients, who have managed to

\footnotetext{
${ }^{56}$ Sheila Duncan, 'Disrupting the Surface of Order and Innocence: Towards a Theory of Sexuality and the Law' [1994] 2 Feminist Legal Studies 1, 22.
} 
shirk much of the penalisation thus far. However, it is possible that such provisions will scare off more decent parlour owners and leave prostitutes in the hands of pimps who fear the law the least: surely the most hardened of criminals.

A further issue within the law is that a prostitute may work by herself from an indoor premises, but if there is more than one prostitute then it is considered a brothel, and therefore illegal. This ensures that prostitutes must work alone, increasing their vulnerability. Those responsible for passing the relevant legislation would inevitably be faced with social and political furore if they were to legalise brothels - a 'not in my back yard' sentiment that works to keep the prostitute from working in safer communities, or within a group. This upholds the prevailing social attitudes towards prostitution that were present during the CD Acts- that, somehow, by being upstanding 'moral' citizens, others should be able to have their safety and wishes supported over that of the prostitute. By participating in criminality, she has somehow lost her privileges to safety and protection, much like the principle barring those involved in criminal activity to use the defence of duress in criminal law. This mindset fails to take into account the potentially coercive nature of the profession, and the ways in which vulnerable women may turn to sex work in order to escape financial hardship. For every sex worker who claims her path into the profession was a voluntarily chosen expression of female autonomy, there is another who has been coerced or threatened with violence, and it is fallacious to assume that a woman has chosen to shun legality and should therefore be left to deal with the consequences. It was the realisation of this social isolation that has enabled sex workers to become the focus of violent attacks such as those by Steven Griffiths (the 'Crossbow Killer') and Peter Sutcliffe. It is noteworthy that the focus in these sorts of crimes have been the murderers 'and the prostitutes', with little attention paid to the individual characters and identities of those murdered. Once again, the women are defined only by their career as a sex worker: falling within the cracks of society and targeted for their vulnerability and lack of protection.

Returning to a Foucauldian understanding of the connection between law and power, we can see that the law acts as a kind of discourse that has established an understanding of prostitutes as a 
category of women (rather than simply a career), emphasising female sexuality as something that can contaminate the morality of the nation. While the law has always permitted prostitution, it has established ways of thinking about it in which women have suffered. This has been achieved alongside medical discourses, and reference to fear of the spread of infection. When thinking about the CD Acts as an embodiment of a medico-legal attack against the spread of venereal disease, one may consider the modern-day equivalent to be that of the fear of prostitutes spreading STDs and AIDS. However, it is not clear that prostitutes actually do contribute towards the spread of such diseases. Kandel holds that female-to-male transmission of AIDS is much less effective than male-to-female transmission, and notes that if prostitutes posed as great a risk to the spread of infection, based on the prostitute sleeping with an average of 1500 men per year, the incidence of AIDS should be far greater $^{57}$. This indicates that this fear is, once again, inherently tied up within the social portrayal of the prostitute as infectious and dirty, both physically and morally. In fact, in McLeod's interviews, many prostitutes insist that they understand the risk that comes with their job, and take great precautions out of both self-interest and ensuring that their clients are healthy ${ }^{58}$. This is not to deny the great risk inherent within the sex industry, and emphasis must be placed upon ensuring that both sex workers and clients are encouraged to have regular check-ups. The key is, rather, that effort should be made to move away from once again scapegoating the prostitute as the cause of the spread of disease, and acknowledging the fact that sexual diseases may be spread through any form of unprotected sex.

Frug argues that the law fixes the female body with meanings, and none more so than legislation regarding prostitution. ${ }^{59}$ The regulation of prostitution:

occurs through a network of cultural practices that endanger sex workers' lives and make their work terrifying. These practices include the random, demeaning...character of anti-prostitution law enforcement...inadequate police

\footnotetext{
57 Minouche Kandel, 'Whores In Court: Judicial Processing of Prostitutes in the Boston Municipal Court in 1990' in Karen Maschke (ed), Pornography, Sex Work and Hate Speech (Garland 1997).

${ }^{58}$ McLeod (n 21).

${ }^{59}$ Frug (n 28).
} 
protection for crimes against sex workers, and unregulated bias against prostitutes and their children in housing, education, the health care system, and in domestic relations law. ${ }^{60}$

Frug's 'maternalisation of the female body' states that, as identities are constructed in contextual and contingent language, '( $\mathrm{t}$ )he legal rules that criminalise prostitution are located in a legal system in which other legal rules legalize sex - rules...that establish marriage as the legal site of sex and that link marital sex to reproduction by, for example, legitimating children born in marriage'. ${ }^{61}$ Because of this, laws on prostitution maternalise the female body, asking women the question of "whether a woman is for illegal sex or...legal, maternalised sex'. ${ }^{62}$ Just as the CD Acts constructed a juxtaposition whereby a woman was either a prostitute or a respectable woman, sexualised or maternalised, modern laws cannot escape from this maternalisation due to the contextual nature of language and knowledge.

What Frug calls the 'legal terrorisation' of the prostitute body means that they turn to pimps as a form of protection, which is further terrorising. She notes that pimps control what the prostitutes do, when they do it, and take her earnings away from her, and that this process is so demeaning that marriage can function as an avoidance mechanism, 'in that...marriage signals that a woman has chosen legal sex over illegal sex'. ${ }^{63}$ One can draw some parallels between the sexualised female body and the terrorised female body, as Frug points out. Both marriage and aligning oneself with a pimp involves turning to a male to provide protection and emotional and physical dependence, acting as a social incentive to reduce the hardship of her position.

It is because of these similarities that some feminists such as Dworkin hold that in no relationship is a woman a genuinely willing participant. ${ }^{64}$ Rather, any feelings of sexual autonomy or even satisfaction that she feels within a relationship may be a product of false consciousness, a process also described by Foucault. ${ }^{65}$ This is the

\footnotetext{
${ }^{60}$ ibid 133.

${ }^{61}$ ibid 134.

62 ibid 134.

63 ibid 133.

${ }^{64}$ Andrea Dworkin, Intercourse (Simon and Schuster 1997).

${ }^{65}$ Foucault (n 1).
} 
understanding that women, as a result of societal conditioning and male psychological force, come to believe that they actually enjoy or are liberated by a sexual relationship (or, indeed, working as a sex worker). One might argue that this is the highest form of Foucauldian selfsurveillance: society has manipulated the female into falsely believing that she is happy in a traditionally patriarchal relationship, or is liberated by being a sex worker.

Appeals to false consciousness may be enlightening in regards to the potential psychological processes whereby women convince themselves that sex work is a liberating experience. However, they do nothing to mitigate against the emotional and physical risks that the sex worker has to endure on a daily basis. To tell her that she is not really satisfied, or that her choice is a product of false consciousness, does not change the choice or liberate the oppressed. If the abolition of prostitution is the ultimate goal, then the process must be a slow, steady inculcation of the notions of female autonomy from male oppression and ultimate sexual worth, rather than a heavy-handed attempt by abolitionists or radical feminists to tell the prostitute that they do not understand what they are choosing, and should not be free to choose it. This approach would likely only serve to provoke indignation in those who already resent Government intervention in what they consider to be a freely chosen career.

Attention must be drawn to the advent of a different kind of sex worker, a far cry from the traditional image of the working class, diseased prostitute who is the scourge of the streets. This is the escort, whose modus operandi is to frequent expensive hotels, attend dinner dates or social activities and charge high prices for her services. It may be argued that this is the standard by which all sex workers should conduct their services, with their whereabouts constantly monitored by an agency, protecting her from client aggression and dangers in a way that the street worker cannot be. However, it is important to be careful not to impose a middle-class interpretation on what sex work should resemble, subconsciously approving of escort agencies because they portray the female escort as financially secure, well-dressed and therefore of a higher class, and subsequently a higher worth. By insisting that the prostitute 
'Other' resemble the dominant 'Same', we neglect to address the inherent issues within sex work, and merely create a wolf in sheep's clothing.

\section{H. Regulatory Alternatives}

If the law so far has done little to improve the status of the female and her control over her own body, what are the potential alternatives? Although there have been a number of nuanced approaches to the regulation of sex work in different jurisdictions, it is worth examining the two broad camps: the eradication approach and the regulationist approach.

\section{The Eradication Approach}

The eradication approach is taken in the Netherlands, Sweden and the UK. It generally consists of two distinct standpoints:

(1) Moralist, which sees the prostitute as deviant and a threat to traditional family values. This view usually calls for the prohibition or suppression of prostitution through strong punitive sanctions.

(2) Abolitionist, which is usually associated with radical feminist analyses of prostitution that see those involved in prostitution as victimised by the male clients and pimps.

The abolitionist approach has been criticised for making circumstances even more dangerous for a sex worker, who is forced to exist on the fringes of the law. Silbert found that $70 \%$ of prostitutes he surveyed claimed to have been raped an average of 8-10 times each year. ${ }^{66}$ When questioned, they claimed that they did not report the crimes because the police usually failed to take them seriously, regarding rape as something of an occupational hazard. The prostitute appears to effectively sacrifice her consent by virtue of her career choice. In stark juxtaposition to the soldiers who should not be subjected to an examination for venereal disease out of respect for the male body, it seems that the prostitute can undergo such intrusive examinations, or fall victim of rape, because she has somehow demeaned herself to such an extent that her physical wellbeing is no longer considered worthy of protection. Indeed, it is interesting to observe that the paternalism that called for prostitution to be

${ }^{66}$ Kandel (n 57). 
abolished on the grounds of danger to the female body is quietened in respect of such risks actually turning into real harms.

Criminalisation and abolition further supports the notion of the prostitute as the isolated Other, encouraging the treatment of sex workers as second-class citizens. A Foucauldian appreciation of the potential power of the law as a conditioning influence may lend something to our understanding of how the law serves to keep the prostitute amongst the fringes of society. With the stigma of criminalisation comes a socially coercive tool, perpetrating notions of morality and subconscious beliefs about the female sex worker. The message is implicit, but effective: if the law does not respect the prostitute, then neither should others.

Further criticisms of the abolitionist approach claim that it is founded upon a misunderstanding of the social acceptability of commercial sex. Those involved in the trade should not be labelled as deviant, as social perception has moved on since the CD Acts. Hester and Westmarland found that clients were generally married, middle-aged men, in full-time employment and with no criminal record. ${ }^{67}$ McLeod's interviews with prostitutes correspond with this finding, stating that 'without exception, prostitutes put forward the identity of their clients generally as being that of "Mr Average", ${ }^{68}$ coming from a number of high-earning jobs and educational backgrounds. This is significant in that the criminal law attempts to place a label on those who commit crimes and deviating from the acceptable social attitudes, criticising their behaviour as something that needs to be reformed, or something that is socially dangerous.

If the clients who use sex workers are generally non-deviant, what benefit is there in punishing them? It depends what utility the law poses. If criminalisation is based upon labelling social deviants and ensuring that they are not a danger to society, then perhaps the law needs to modernise itself and accept that views on prostitution have changed. However, it is not particularly evident that this is the case, or that criminalisation should merely serve to categorise behaviour as deviant or acceptable. Perhaps the law is attempting to portray a deeper belief that using a woman for sexual

\footnotetext{
${ }^{67}$ Marianne Hester and Nicole Westmarland, Tackling Street Prostitution: Towards an Holistic Approach (Home Office Research Study 279 2004) $<$ http://dro.dur.ac.uk/2557/1/2557.pdf $>$ accessed 25 February 2011.

${ }^{68}$ McLeod (n 21) 60.
} 
intercourse and for her body a basic, absolute wrong. If this were the case, then why is prostitution therefore legal? It is this level of incoherence in the law and its aims and goals that create problems and confusion.

\section{The Regulationist Approach}

This approach permits prostitution to occur in places and forms specified by the law so as to limit its harmful effects.

It comes in two broad forms:

1. Decriminalisation- the removal of existing offences from statutes without establishing a regulatory apparatus, such as in New South Wales and New Zealand.

2. Legislation- providing for the licensing of some forms of prostitution, which are subject to the surveillance of police or other state bodies to ensure that they comply.

An example of the regulationist approach is the licensed house in Nevada, in which prostitutes who work within the house are forced to undergo tests that check for all STDs and addictions. However, the system of the licensed house aims predominantly to reduce the spread of venereal disease and privatising prostitution to keep it out of the public eye, rather than concerning itself with protecting the female prostitute. Tong states that they create a pool of 'sacrificial victims' to satisfy men on demand. ${ }^{69}$ Far from a controlled but liberating process, the licensed house can be seen as another way of oppressing and controlling the female body. ${ }^{70}$

Attempts to create geographically regulated areas for sex workers were also considered closer to home. Howell, Beckingham and Moore explored the 2005 proposals to establish 'tolerance zones' for prostitutes in Liverpool, noting the similarities between principles of "containment" and "localisation""71 in the proposals and that of the Victorian municipal management of prostitution. They held that:

\footnotetext{
${ }^{69}$ Rosemarie Tong, Women, Sex and the Law (Rowman \& Littlefield 1983) 59.

${ }^{70}$ Anita Morse, 'Pandora's Box: An Essay Review of American Law and Literature on Prostitution' [1998] Wisconsin Women's Law Journal 21.

${ }^{71}$ Howell (n 43).
} 
...the assignation of spaces formally or informally dedicated to the prosecution of sex work raises questions concerning...the role of geographies of gender and sexuality in structuring space...geographers have demonstrated that the spatiality of the policing and regulation of prostitution necessarily reproduces wider notions of moral order and identity. ${ }^{72}$

As Foucault notes, the Other Victorians were shifted in a geographically located area of tolerance — 'the brothel and the mental hospital'. ${ }^{73}$ This link between spatial ordering, morality and body politics harks back to the predominant concern of the public/private divide of the Wolfenden Report, serving to reinforce the prostitute as the Other by forcing her to exist in both a socially and geographically separate sphere. To relegate the prostitute to an alternate location does nothing for her historical position as a social pariah. It is not demanded that the general society must realign its own morality to accept what the sex worker does and the commodification of the female body. Indeed, this article seeks to try and achieve an uneasy balance between accepting that there is something inherently disconcerting about the inevitability of the sale of the female body, and attempting to regulate the process in order to ensure that women who must enter the profession are not abandoned by the State. The benefits of the regulationist model are that it acknowledges that the inescapable nature of prostitution, and attempts to regulate this by making it safer, ensuring that women are informed about their decisions and are offered paths out of the commercialised sex profession if they so choose. Under this approach, sex is seen as a form of service, much like other professions such as masseurs and care-workers.

This approach puts the emphasis upon including sex workers in society and submerging them within everyday social life by emphasising and playing upon the similarities between sex workers and workers of all different times- rejecting the 'Otherness' of the 'Other'. On this view, sex workers are not victims, but making conscious decisions and controlling their own earning capacity. This view has been upheld by many prostitutes, who argue that, far from the image of the downtrodden drug addict who gets caught up in prostitution, they are rational women who

\footnotetext{
${ }^{72}$ ibid 234.

${ }^{73}$ Foucault (n 1) 4.
} 
have decided to take control of their own lives. Sex work, particularly in a recession, enables them to keep up with Christmas presents and nursery fees; it helps them to take control over a situation in which they would otherwise feel helpless.

However, the distinction between prostitution and other services is that one, importantly, involves sex. Pateman argues that:

Services and labour power are inseparably connected to the body and the body is, in turn, inseparably connected to the sense of self.... When sex becomes a commodity in the capitalist market so, necessarily, do bodies and selves. The prostitute cannot sell sexual services alone; what she sells is her body. ${ }^{74}$

Andrea Dworkin agrees from a Kantian perspective, stating:

In prostitution, no woman stays whole. It is impossible to use a human body in the way women's bodies are used in prostitution and have a whole human being at the end of it. ${ }^{75}$

For a multitude of reasons, sex is inextricably bound up with something spiritually deeper than the physical act itself, unlike the provision of other physical services. These roots may originate from the understanding of sexual intercourse within religion and Christianity as something more than an act of the flesh, creating an intimate bond with both the marital partner and God. However, while much has been said about the connection between power, sexual discourse and the hysterised female body, it is important to note that it is not only the fulfilment of sexual desire that encourages clients to turn to prostitution. They may long for simple physical interaction, conversation, or the realisation of fantasies that they are not willing, or unable to, articulate to the partners or spouses.

When one focuses on the work of a prostitute as solely sexual activities, it can be easy to ignore the myriad of services that a sex worker provides, and, correspondingly, the number of reasons a client may wish to utilise those services. For those who are unable to discharge a sexual

\footnotetext{
${ }^{74}$ Pateman (n 25) 562.

75 Andrea Dworkin, 'Prostitution and Male Supremacy' (Speech presented at University of Michigan Law School, MI., 31 October 1992) <http://www.nostatusquo. com/ACLU/dworkin/MichLawJourI.html> accessed 20 February 2011.
} 
fantasy within the confines of their daily lives, the sex worker may provide a form of escapism; a method by which a client can evade the mundane repetition of his life by acting out those otherwise restricted desires. On this view, sex work may be treated as a form of therapy, by which the prostitute provides a form of sexual and emotional knowledge and support. However, this requires a shift of norms towards the medicalisation of sexual habits, and an increased understanding and acceptance of the clients as ill, or needing care. This is likely to be met with reluctance, particularly since the notion of the 'natural' male sexual desire has been propagated throughout history as something organic and endemic. Rather than inspire a normative shift and provoke new sexological discourses, clients may be more likely to turn to sex tourism in jurisdictions with more lenient approaches to sex work.

\section{CONCLusion}

Despite the issues with the regulation model outlined above, it is submitted that this is to be preferred over the purgatory of partial criminalisation that sex workers currently exist in. It is undeniable that prostitution raises uneasy feelings regarding the objectification of the female body, and the sale of an act that has been propagated by social morality, religion and the media as being something valuable, emotional and intimate. However abhorrent the idea of prostitution may be, to relegate the sex worker to the fringes of society and maintain the image of the prostitute as sub-human does nothing for the cause of women's rights, or the fight to protect them from the dangers of exploitation and oppression. Furthermore, a complete prohibition on prostitution fails to appreciate the apparent inevitability of the sex trade industry, further pushing the prostitute into the underbelly of society and allowing her to be manipulated in the shadows of the law.

While the ultimate goal is a society in which the demand of the female body for sexual pleasure would not exist, it is currently more important that the industry be rendered safe, controlled, regulated, with a view to gradually improving the status of prostitutes and public awareness. These woman are not subhuman, or nymphomaniacs, or diseased harpies. They are women who believe that they have chosen a life that enables them to continue to get by when the welfare system has 
failed them; women who believe that their choices are their own; women whose only alternative is even more poverty and deprivation. To take away even more of their freedom in the name of championing feminist rights is not only counterproductive, but stunts any potential progress in moving away from the influence of the Contagious Diseases Acts, and working towards a safer existence for women. 